\title{
An Autopsy Study of Atherosclerotic Changes in Coronary Arteries at B.P. Koirala Institute of Health Sciences
}

\author{
Sudhir Raman Parajuli ${ }^{1}$, Bishwonath Yadav $^{1}$, Prahlad Karki ${ }^{2}$, Paricha Upadhyaya ${ }^{3}$, Shivendra Jha ${ }^{1}$ \\ ${ }^{1}$ Department of Forensic Medicine, B.P. Koirala Institute of Health Sciences, Dharan, Nepal \\ ${ }^{2}$ Department of Internal Medicine, B.P. Koirala Institute of Health Sciences, Dharan, Nepal \\ ${ }^{3}$ Department of Pathology, B.P. Koirala Institute of Health Sciences, Dharan, Nepal
}

\section{CORRESPONDENCE}

\author{
Dr. Sudhir Raman Parajuli, \\ Department of Forensic Medicine, Manipal \\ College of Medical Sciences, Pokhara, \\ Nepal \\ Email: drsudhirramanparajuli@yahoo.com
}

\section{ARTICLE INFO}

Article History

Submitted: 01 November, 2020

Accepted: 19 December, 2020

Published: 8 February, 2021

Source of support: None

Conflict of Interest: None

Copyright : CThe Author(S) 2020 This is an open access article under the Creative Common Attribution license CC-BY 4.0

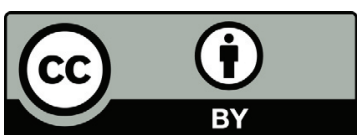

\begin{abstract}
Introduction: Atherosclerosis is a giant killer and the incidence of atherosclerosis in coronary arteries is rapidly increasing. The study was designed to assess the atherosclerotic lesions in coronary artery and to correlate the risk factors related to prevalence of atherosclerosis.
\end{abstract}

Methods: Heart from 100 medico legal autopsy cases ranging between ages 15 to 35 years which came to BPKIHS Dharan were taken for this study and processed for coronary arteries using conventional technique. They were then studied,and grading was done based on Modified American Heart Association (AHA) classification of atherosclerosis.

Results: Intimal thickening was noted in more than $90 \%$ in all three coronary arteries followed by intimal xanthoma whereas intermediate lesion for atherosclerosis was not found. Age, gender, smoking and alcohol in relation to atherosclerosis were found to be of no significance.

Conclusion: The study highlights the impact of atherosclerotic lesions in the Eastern region of Nepal. Meticulous postmortem examination along with histopathological study is the best possible way to study atherosclerotic disease in humans and risk factors associated with it.

Keywords: Atherosclerosis; Autopsy; Coronary artery.

\section{INTRODUCTION}

Coronary atherosclerosis is the most frequent cause of ischemic heart disease. The composition and vulnerability of the atherosclerotic plaque determines the development of acute coronary syndromes. ${ }^{1}$ Inflammation has a key role in the pathogenesis of atherosclerosis and it is supported by numerous factors such as modified LDL, hypertension, diabetes mellitus, free radicals and, in particular, by infectious agents such as Chlamydia pneumoniae. ${ }^{2}$ Atherosclerosis is characterized by intimal lesions called atheromas, agents such as Chlamydia agents lesions called atheromas, atheromatous or fibro fatty plaques, which protrude into and obstruct vascular lumens and weaken the underlying media. ${ }^{3}$

Atherosclerosis can affect the kidneys either directly (e.g. renal artery stenosis) or as a frequent site of atheroembolic disease. ${ }^{4}$ Atherosclerosis is a giant killer and the incidence of atherosclerosis in coronary arteries is rapidly increasing. Myocardial infarction alone is responsible for $20 \%$ to $25 \%$ of all deaths in United States. ${ }^{3}$ The incidence of CAD is less common, amongst Nigerian as compared to the other races. In India, it accounts for $85 \%$ of all the sudden deaths. ${ }^{5}$ This study is defined to assess the histomorphological atherosclerotic changes in coronary arteries autopsy by applying the modified AHA classification of atherosclerosis based on morphological descriptions to find out the age, gender and other risk factors related prevalence of atherosclerosis in Eastern region of Nepal. ${ }^{6}$

This specific classification is used since it offers better categorization of atherosclerotic lesions based on morphological descriptions compared to the earlier AHA classification, which was too rigid with descriptions of lesions (Table 1). Defining these intermediate lesions is of great importance as they are the precursor lesions of future advanced atherosclerosis.

\section{METHODS}


The present study is a hospital based cross sectional study carried out in dead bodies brought to BPKIHS mortuary from Eastern region of Nepal and was carried out from September 2014 to August 2015. Ethical clearance for the study was taken from Ethical Review Board, BPKIHS before the commencement of the study. Autopsy subject was identified, examined, and postmortem examination was done after obtaining requisition and inquest paper from the police in medico legal autopsies and after that cause of death were made. Historical data regarding age, gender, past medical illness, medications, familial and drug habits, habits such as alcohol consumption and smoking were noted from the deceased relatives and from the death certificate or police where available.

Heart and three coronary arteries: right (RCA), left anterior descending artery(LAD) and left circumflex arteries(LCA) were then examined grossly and each sectioned at 3-5 $\mathrm{mm}$ intervals to examine for any atherosclerotic plaques through microscopic assessmentand grading was done according to modified AHA classification of atherosclerosis based on morphological descriptions for individual artery. Sample size of the study was 100 . Data was collected and entered in MS EXCEL 2013 and analysis using SPSS 11.0 version.

\begin{tabular}{|c|c|c|}
\hline Description & & Thrombosis \\
\hline \multicolumn{3}{|l|}{$\begin{array}{l}\text { Non } \\
\text { atherosclerotic } \\
\text { lesions }\end{array}$} \\
\hline $\begin{array}{l}\text { Intimal } \\
\text { thickening }\end{array}$ & $\begin{array}{l}\text { The normal accumulation of } \\
\text { Smooth Muscle Cells (SMCs) } \\
\text { in the intima in the absence of } \\
\text { lipid or macrophage foam cells }\end{array}$ & Absent \\
\hline $\begin{array}{l}\text { Intimal xan- } \\
\text { thoma, or "fatty } \\
\text { streak" }\end{array}$ & $\begin{array}{l}\text { Luminal accumulation of foam } \\
\text { cells without a necrotic core or } \\
\text { fibrous cap. Based on animal } \\
\text { and human data, such lesions } \\
\text { usually regress. }\end{array}$ & \\
\hline \multicolumn{3}{|l|}{$\begin{array}{l}\text { Progressive } \\
\text { atherosclerotic } \\
\text { lesions }\end{array}$} \\
\hline $\begin{array}{l}\text { Pathological } \\
\text { intimal thicken- } \\
\text { ing }\end{array}$ & $\begin{array}{l}\text { SMCs in a proteoglycan-rich } \\
\text { matrix with areas of extra } \\
\text { cellular lipid accumulation } \\
\text { without necrosis }\end{array}$ & Absent \\
\hline Erosion & $\begin{array}{l}\text { Luminal thrombosis; plaque } \\
\text { same as above }\end{array}$ & $\begin{array}{l}\text { Thrombus } \\
\text { mostly mural } \\
\text { and infrequent- } \\
\text { ly occlusive }\end{array}$ \\
\hline $\begin{array}{l}\text { Fibrous cap } \\
\text { atheroma }\end{array}$ & $\begin{array}{l}\text { Well-formed necrotic core with } \\
\text { an overlying fibrous cap }\end{array}$ & Absent \\
\hline Erosion & $\begin{array}{l}\text { Luminal thrombosis; plaque } \\
\text { same as above; no communica- } \\
\text { tion of thrombus with necrotic } \\
\text { core }\end{array}$ & $\begin{array}{l}\text { Thrombus } \\
\text { mostly mural } \\
\text { and infrequent- } \\
\text { ly occlusive }\end{array}$ \\
\hline
\end{tabular}

\begin{tabular}{lll}
$\begin{array}{l}\text { Thin fibrous cap } \\
\text { atheroma }\end{array}$ & $\begin{array}{l}\text { The normal accumulation of } \\
\text { Smooth Muscle Cells (SMCs) } \\
\text { in the intima in the absence of } \\
\text { lipid or macrophage foam cells }\end{array}$ & Absent \\
Plaque rupture & $\begin{array}{l}\text { A thin fibrous cap infiltrated } \\
\text { by macrophages and lympho- } \\
\text { cytes with rare SMCs and an } \\
\text { underlying necrotic core }\end{array}$ & $\begin{array}{l}\text { Absent; } \\
\text { may contain } \\
\text { intra-plaque } \\
\text { hemorrhage/ } \\
\text { fibrin }\end{array}$ \\
Calcified nodule & $\begin{array}{l}\text { Fibro atheroma with cap } \\
\text { disruption; luminal thrombus } \\
\text { communicates with the } \\
\text { underlying necrotic core }\end{array}$ & $\begin{array}{l}\text { Thrombus } \\
\text { usually } \\
\text { occlusive }\end{array}$ \\
\hline
\end{tabular}

\section{RESULTS}

A total of 406 autopsies were performed in the department of forensic medicine in one year from august 2014 to august 2015. Of those 100 cases were taken of age groups 15 to 35 years irrespective of the cause of death. The mean age was 24.81 years with standard deviation of 5.88. Majority of the population were literate being $25 \%$ of the total population.

\begin{tabular}{llll}
\hline \multicolumn{4}{l}{ Table 2: Coronary artery atherosclerotic lesions } \\
\hline Lesions & RCA & LAD & LCA \\
\hline Intimal thickening & 88 & 90 & 96 \\
Intimal xanthoma & 11 & 10 & 4 \\
$\begin{array}{l}\text { Progressive intimal thicken- } \\
\text { ing }\end{array}$ & 1 & 0 & 0 \\
Total & $\mathbf{1 0 0}$ & $\mathbf{1 0 0}$ & $\mathbf{1 0 0}$
\end{tabular}

Major cause of death in this age group was hanging followed by road traffic accident and poisoning. Majority of the population were homemaker followed by self-employed and student. Unemployed and farmer share equal percentage of population of $9 \%$. $13 \%$ of the population were unemployed. About half of the population group(52\%) were smokers. More than half of the population(56\%) consumed alcohol. (Figure 1) Intimal thickening was noted in most of the individuals followed by intimal xanthoma (Table 2).

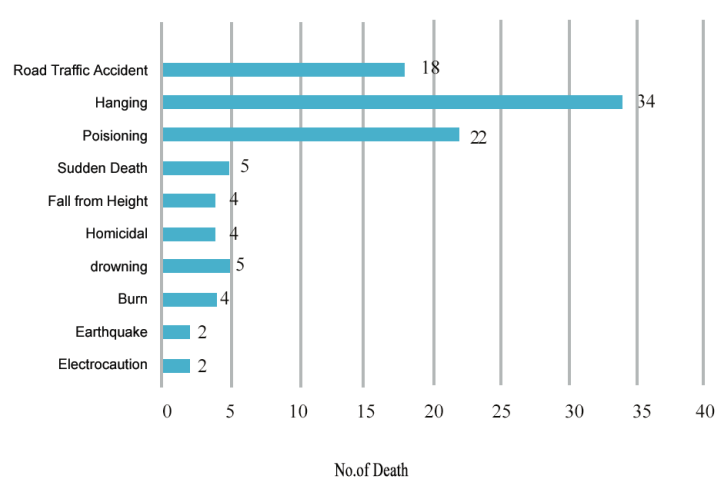

Figure 1: Cause of death among study group 


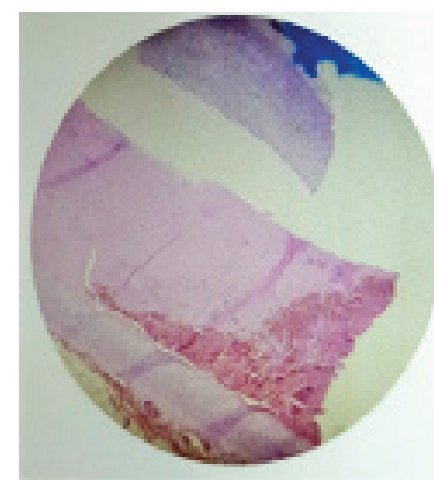

Fig : 2a

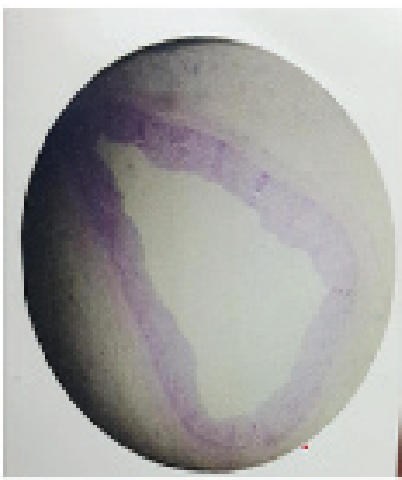

Fig : 2c

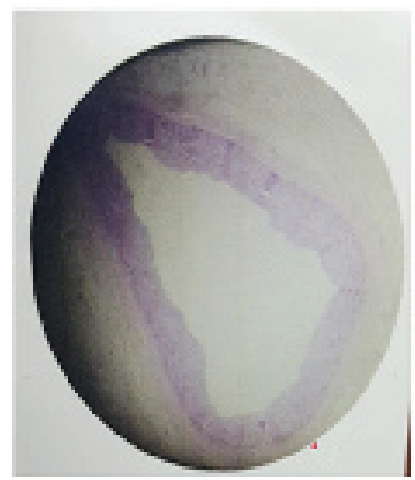

Fig : $2 b$
Figure 2

Microphotograph showing coronary artery Intimal thickening(2a), intimal xanthoma(2b) and Progressive intmal thickening (2c) using Hematoxylin and Eosin stain.
In this study, we tried to show association of atherosclerotic lesions with various other socio-demographic and behavioral predictors (Table $2 \mathrm{a}, 2 \mathrm{~b}$ and $2 \mathrm{c}$ ).

\begin{tabular}{|c|c|c|c|c|}
\hline \multirow[b]{2}{*}{ Characteristics } & \multirow[b]{2}{*}{ Category } & \multicolumn{3}{|l|}{ LAD } \\
\hline & & $\begin{array}{l}\text { Intimal } \\
\text { thickening }\end{array}$ & $\begin{array}{l}\text { Intimal } \\
\text { xanthoma }\end{array}$ & $\begin{array}{l}\mathrm{p}- \\
\text { value }\end{array}$ \\
\hline \multirow[t]{2}{*}{ Age } & $15-25$ & & $3(3.2 \%)$ & \multirow[t]{2}{*}{0.090} \\
\hline & $26-35$ & $335(83.3 \%)$ & $7(16.7 \%)$ & \\
\hline \multirow[t]{2}{*}{ Gender } & Male & $355(94.8 \%)$ & $6(10.7 \%)$ & \multirow[t]{2}{*}{1.000} \\
\hline & Female & $40(90.9 \%)$ & $4(9.1 \%)$ & \\
\hline
\end{tabular}

Table 2b: Association of LCA with age and gender

\begin{tabular}{lllll}
\multirow{2}{*}{ Characteristics } & Category & $\begin{array}{l}\text { LCA } \\
\text { Intimal } \\
\text { thickening }\end{array}$ & $\begin{array}{l}\text { Intimal } \\
\text { xanthoma }\end{array}$ & $\begin{array}{l}\text { p- } \\
\text { value }\end{array}$ \\
Age & $15-25$ & $56(96.6 \%)$ & $2(3.4 \%)$ & 1.000 \\
\multirow{2}{*}{ Gender } & $26-35$ & $40(95.2 \%)$ & $2(4.8 \%)$ & \\
& Male & $53(94.6 \%)$ & $3(5.4 \%)$ & 0.628 \\
& Female & $43(97.7 \%)$ & $1(2.3 \%)$ &
\end{tabular}

In this study no significant association was seen between age and atherosclerotic lesions in RCA, LAD and LCA. Similarly, although males were seen having more intimal xanthomatous lesions in LAD and LCA, this was however not significant.
Table 2c: Association of RCA with age and gender

\begin{tabular}{lllll}
\multirow{2}{*}{ Characteristics } & Category & RCA & & \\
& & $\begin{array}{l}\text { Intimal } \\
\text { thickening }\end{array}$ & $\begin{array}{l}\text { Intimal } \\
\text { xanthoma }\end{array}$ & $\begin{array}{l}\text { p- } \\
\text { value }\end{array}$ \\
Age & $15-25$ & $52(89.7 \%)$ & $6(10.3 \%)$ & 0.552 \\
\multirow{2}{*}{ Gender } & $26-35$ & $36(85.7 \%)$ & $6(14.3 \%)$ & \\
& Male & $50(89.3 \%)$ & $6(10.7 \%)$ & 0.760 \\
& Female & $38(86.4 \%)$ & $6(13.6 \%)$ &
\end{tabular}

Among the alcohol consumers, intimal xanthoma was seen in $7.1 \%$ of the cases, and this was not found to be statistically significant $(p=0.328)$ in LAD. Smoking status was also not found to be associated with atherosclerotic lesions.(Table 3a,3b,3c)

Table 3a: Association of LAD with Alcohol consumption

\begin{tabular}{lllll}
\multirow{2}{*}{ Characteristics } & Category & $\begin{array}{l}\text { LAD } \\
\text { Intimal } \\
\text { thickening }\end{array}$ & $\begin{array}{l}\text { Intimal } \\
\text { xanthoma }\end{array}$ & $\begin{array}{l}\text { p- } \\
\text { value }\end{array}$ \\
Alcohol & Yes & $52(92.9 \%)$ & $4(7.1 \%)$ & 0.328 \\
& No & $38(86.4 \%)$ & $6(13.6 \%)$ & \\
Smoking & Yes & $48(92.3 \%)$ & $4(7.1 \%)$ & 0.514 \\
& No & $42(87.5 \%)$ & $6(13.6 \%)$ &
\end{tabular}

Table 3b: Association of LCA with Alcohol consumption and smoking

$\begin{array}{lllll}\text { Characteristics } & \text { Category } & \begin{array}{l}\text { LCA } \\ \text { Intimal } \\ \text { thickening }\end{array} & \begin{array}{l}\text { Intimal } \\ \text { xanthoma }\end{array} & \begin{array}{l}\text { p- } \\ \text { value }\end{array} \\ \text { Alcohol } & \text { Yes } & 55(98.2 \%) & 1(1.8 \%) & 0.317 \\ \text { Smoking } & \text { No } & 41(93.2 \%) & 3(6.8 \%) & \\ & \text { Yes } & 51(98.1 \%) & 1(1.9 \%) & 0.348 \\ & \text { No } & 45(93.8 \%) & 3(6.2 \%) & \end{array}$

Table 3c: Association of LAC with Alcohol consumption

\begin{tabular}{lllll|} 
Characteristics & Category & $\begin{array}{l}\text { LAC } \\
\text { Intimal } \\
\text { thickening }\end{array}$ & $\begin{array}{l}\text { Intimal } \\
\text { xanthoma/ } \\
\text { progres- } \\
\text { sive intimal } \\
\text { thickening }\end{array}$ & $\begin{array}{l}\text { p- } \\
\text { value }\end{array}$ \\
Alcohol & Yes & $50(89.3 \%)$ & $6(10.7 \%)$ & 0.223 \\
Smoking & No & $38(86.4 \%)$ & $6(13.6 \%)$ & \\
& Yes & $48(92.3 \%)$ & $4(7.7 \%)$ & 0.348 \\
& No & $40(83.3 \%)$ & $8(16.7 \%)$ &
\end{tabular}

\section{DISCUSSION}

Coronary artery disease (CAD) is associated with the number of risk factors causing coronary atherosclerosis. Coronary artery stenosis is mostly caused by coronary 
atherosclerosis. ${ }^{7}$ Coronary Heart Disease incidence is decreasing in Western Europe, the United States and in Australia but is steeply increasing in Asia, Central and Eastern Europe, and Africa. ${ }^{8}$ In past few years, Eastern region of Nepal has undergone a rapid change in lifestyle, habit modification, stress, strain. In the present studysufficient effort has been made to study the effects of these habits on atherosclerosis.Atherosclerosis is a multi-factorial disease affected by various factors, such as smoking, alcohol consumption, presence of stress and strain in life, personality characteristics, etc. Many studies have been undertaken in the past to study association of various factors leading to atherosclerosis, ultimately leading to CAD. ${ }^{5,9}$ In a study done by Adhikari CM et al. in a capital city heart center $70 \%$ patients were smokers who were brought for coronary heart disease in age group up to 40 years. ${ }^{10}$ Study done in Central Nepal by Koju R et al. showed that among the established cardiovascular risk factors, gender, diabetes mellitus and smoking are significantly associated with coronary stenosis among CAD patients which is in contrast to our study. ${ }^{7}$ In our study, non-atherosclerotic lesions were seen in almost all cases except in one case where the right coronary artery showed atherosclerotic lesion. A similar study using same classification conducted by Viral M. Bhanvadia et al. showed non-atheromatous lesions of $40 \%$ and atherosclerotic lesion of $60 \%$. Our study showed a higher degree of involvement of atherosclerosis in LAD (42\%) as compared to LCA (40\%) and RCA (39\%). ${ }^{11}$

This study also showed contrast finding to that of Sudha et al where atherosclerotic lesions in LAD contributed (47\%). Also, study carried out by Thej et al. and Yazdi et al. in Iran, showed more involvement of LAD (60\%) in atherosclerosisin comparison to RCA (50\%), and $\mathrm{LCA}(42.5 \%)$ respectively. ${ }^{12,6,13} \mathrm{Garg} \mathrm{M}$ et al. in his study concluded that atheroma have been seen above the age of 15 years, but significant atheroma appeared after third decade onwards and thereafter there is a gradual increase in both its frequency and severity from second to sixth decade.Commonest type of atherosclerosis was grade 3 described as intermediate lesion or pre-atheroma. Our study showed no atherosclerotic lesions in almost all subjects. This finding is surprisingly opposite to that of the studies conducted in different parts of the world. This could be attributed to the fact that in our study the subjects were free from diabetes, hypertension, and other cardiac illness despite being smokers and alcoholics.

In recent years, Magnetic Resonance Imaging (MRI) has emerged as a very promising technique for studying atherosclerotic diseases in humans, and various studies have proved their association with histopathological findings. Study done by Everis P. S et al. demonstrated good agreement between coronary artery morphometrical measurements obtained by high resolution $\mathrm{MRI}$ and histopathology in an ex-vivo experimental model.15In a country like Nepal where facility of MRI is limited and costly, investigation with these modalities are beyond the capacity of people in both living and dead. In Nepal autopsy-based research pertaining to atherosclerosis and its associated risk factors is lacking. Therefore, autopsy and histopathological based studiesin this topic covering a larger sample could be beneficial in confirming the association between atherosclerosis and its risk factors.

\section{CONCLUSION}

The study showed unexpectedly lower prevalence of atherosclerosis in younger age group with no significant association between atherosclerosis and its risk factors. Further, study with large sample size is required to better elucidate the association between the two. Histopathological studies provide the most accurate clues to a better understanding of human coronary artery disease. Hence, meticulous postmortem examination along with histopathological study is the best possible way to study atherosclerotic disease in humans and risk factors associated with it.

\section{REFERENCE}

1. Amel E, Prathiba D, Kumar S. Morphological and morphometric analysis of coronary atherosclerosis--an autopsy study. Indian J Pathol Microbiol. 2006;49(2):23942.

2. Gaudio E, Carpino G, Grassi M, Musca A. Morphological aspects of atherosclerosis lesion: past and present. Clin Ter. 157(2):135-42.

3. Kumar, Abbas, Fausto. Robbins and Cotran Pathological Basis of Disease. 7th ed. $516 \mathrm{p}$.

4. Kasper et al. Harrison's Principles of Internal Medicine. 16th ed. 1425 p.

5. Singh H, Oberoi S, Gorea R, Bal M. Atherosclerosis in coronaries in Malwa Region of Punjab. JIAFM. 2005;27(4):236-9.

6. Thej MJ, Kalyani R, Kiran J. Atherosclerosis in coronary artery and aorta in a semi-urban population by applying modified American Heart Association classification of atherosclerosis: An autopsy study. J Cardiovasc Dis Res. 2012 Oct;3(4):265-71.

7. Koju R, Humagain S, Khanal K. Association of cardiovascular risk factors and coronary artery lesion among coronary 
artery disease patients. Kathmandu Univ Med J. 12(46) :137-40.

7. Koju R, Humagain S, Khanal K. Association of cardiovascular risk factors and coronary artery lesion among coronary artery disease patients. Kathmandu Univ Med J. 12(46):137-40.

8. Assmann G, Cullen P, Jossa F, Lewis B MM. Coronary heart disease: Reducing the risk: The scientific background to primary and secondary prevention of coronary heart disease. A worldwide view. International task force for the prevention of coronary heart disease. Arter Thromb Vasc Biol. 1999;19:1819-24.

9. Abraham Joseph, MD, FACC, Douglas Ackerman, MD, J. David Talley, MD, FACC,John Johnstone, MD, FACC, Joel Kupersmith, MD F. Manifestations of Coronary Atherosclerosis in Young Trauma Victims-An Autopsy Study. JACC. 22(2):459-67

10. Adhikari, C., Rajbhandari, R., Limbu, Y., Malla, R., Sharma, R., Rauniyar, B., Rajbhandari, S., Baidya, S., Sharma, D., Maskey, A., \& KC, M. (2013). A study on major cardiovascular risk factors in Acute Coronary Syndrome (ACS) patient 40 years and below admitted in CCU of Shahid Gangalal National Heart Center. Nepalese Heart Journal, 7(1), 20-4.
11. Viral M. Bhanvadia et al. Study of Coronary Atherosclerosis by Modified American Heart Association Classification of Atherosclerosis-An Autopsy Study. J Clin Diagnostic Res. 7(11):2494-7.

12. Sudha M L, Sundaram S, Purushothaman K R, Kumar P S PD. Coronary atherosclerosis in sudden cardiac death: An autopsy study. Indian J Pathol Microbiol. 2009;52:486-9.

13. Yazdi A, Rezaei A, Azari J, Hezazi A, Shakeri M, Shahri M. prevalence of atherosclerotic plaques in autopsy cases with non cardiac death. Iran J Pathol. 2009;4:101-4.

14. Garg M, Aggarwal AD, Kataria SP. Original Research Paper Coronary Atherosclerosis and Myocardial Infarction An Autopsy Study. 2011;33(1):971-4.

15. Gomes EPSG, Rochitte CE, Azevedo CF, Lemos PA, Gutierrez PS, César LAM. Ex-vivo Assessment of Coronary Artery Atherosclerosis by Magnetic Resonance Imaging: Correlation with Histopathology. Open Cardiovasc Med J. 2014;8:26-34. 